レーザーオリジナル

$$
\begin{gathered}
\text { レーザーアブレーション加工時における } \\
\text { デブリー付着特性とその除去の実用化 }
\end{gathered}
$$

折井靖 光*.宮本 勇**

(1994年11月4日＼cjkstart受理)

\title{
Characteristics of Debris Formation During Laser Ablation and a Practical Method for Removing the Debris
}

\author{
Yasumitsu ORII* and Isamu MIYAMOTO**
}

(Recived November 4, 1994)

\begin{abstract}
The diameter of the debris deposited by $\mathrm{KrF}$ excimer laser ablation of polyimide has been measured as a function of gas pressure and laser fluence in different ambient gas species including $\mathrm{He}, \mathrm{N}_{2}$, air, $\mathrm{O}_{2}$, and $\mathrm{Kr}$. It was shown that the amount of the debris is decreased in ambient gases with low masses or at low pressures where generation of the blast wave can be suppressed. The relationship between the measured debris diameter and the shape of the luminous plume produced by ablation of polyimide was also investigated. $\mathrm{A} \mathrm{XeCl} \mathrm{excimer} \mathrm{laser}$ was successfully implemented in thin film line deletions of a multichip carrier used in highperformance mainframe processors. The amount of the debris on a wire bond pad nearby laser deletion was quantified as an ultrasonic power for wire bonding. The helium gas purge condition was thus optimized to reduce the debris.
\end{abstract}

Key Words: Excimer laser, Ablation, Polyimide, Debris, Blast wave

\section{1. 緒言}

近年, 新しい微細加エッールとして, 紫外領 域で発振するエキシマレーザーが注目を浴びて いる。このレーザーはとくに高分子材料の微細 加工において優れた特性を示し ${ }^{1)}$, 新しい生産 技術の方向を示す可能性を秘めている。

このようなエキシマレーザーの加工特性に注 目し，生産技術へ適用した代表的な例が，沉用
大型コンピューターの心臓部であるマルチ， チップ・モジュール(チップが最大121個搭載可 能なマルチ・チップ・パッケージ)の多層セラ ミックス基板の薄膜製造工程 ${ }^{2}$ および技術変更 のための配線切断工程である。配線の切断工程 に扔いては, 従来の多層セラミックス基板では, ルビーレーザーを使用していたが, 新しい基板 では, 最上層部が可視域で吸収係数の小さいポ リイミドの薄膜層で構成され非常に微細な配線

*日本アイ・ビー・エム(株)野洲工場 ( $5520-23$ 滋賀県野洲郡野洲町大字市三宅800番地)

$* *$ 大阪大学工学部生産加工工学教室 (广565 吹田市山田丘2-1)

* Yasu Plant, IBM Japan, Ltd. (800 Ichimiyake, Yasu-cho, Yasu-gun, Shiga 520-23)

* * Department of Welding and Production Engineering, Osaka University (2-1 Yamadaoka, Suita, Osaka 565) 
層であるために，エキシマレーザーを採用する ことになっだ)。ポリイミドのような高分子材 料は紫外線の吸収係数が大きいのでアブレ一 ション加工による熱影響がほとんどなく，加工 深さの高精度な制御ができ，今回のような薄膜 層を要する高密度な多層セラミックス基板の配 線切断工程において最適な加工方法であるとい える。

その一方で，この種のアブレーション加工で は加工部周囲に微細な分解除去物質が付着する 問題があり，高密度化が進むマルチ・チップ・モ ジュールのパッケージ基板において, 実用上大 きな弊害となっている。以下ではこの付着物を デブリー(Debris)と呼ぶことにするが, 現在ま でポリマーを中心にその付着特性ならびに低減 法に関していくつか報告されている。特に, 大 気中でポリイミドをアブレーション加工する と, 加工周囲に黒い物質(炭素)が付着する ${ }^{4}$ 。 このようなデブリー量を低減する方法として, 静電気を用いる収集 ${ }^{5)}$, 赤外線レーザーにより 付着したデブリーの排除6)，局所真空ノズルに よる吸引7)などが提案されているが，実用上不 十分である。また, Kuperらは, Heのような 分子量の小さいガス雲囲気で加工するとデブ リーを減らすことができることを示し ${ }^{8)}$, Singletonらは, 酸素雰囲気中でポリイミドを加工 すると, 発生するデブリーを二酸化炭素などの ガスにすることが可能であるとしており ${ }^{9)}$, 両 者とも加工霉囲気がデブリー付着を低減する上 で重要な要素であることをブラスト・ウェーブ 理論を使って説明している。

本論文では, 雲囲気ガスや真空度などの加工 雲囲気の条件に加えて，レーザーフルエンスを パラメーターとして加え，ポリイミドにおける デブリー付着範囲の測定及び加工時に発生する プルームの撮影を行い, デブリー付着範囲とプ ルームの形状との関係を明らかにした。また， ブラスト・ウェーブ理論を使って，デブリー付 着を低減する加工条件を総合的に評価した。こ の結果をもとに, 製造工程に適したデブリーを 減らす最適のガスパージの方法を考案し, 多層
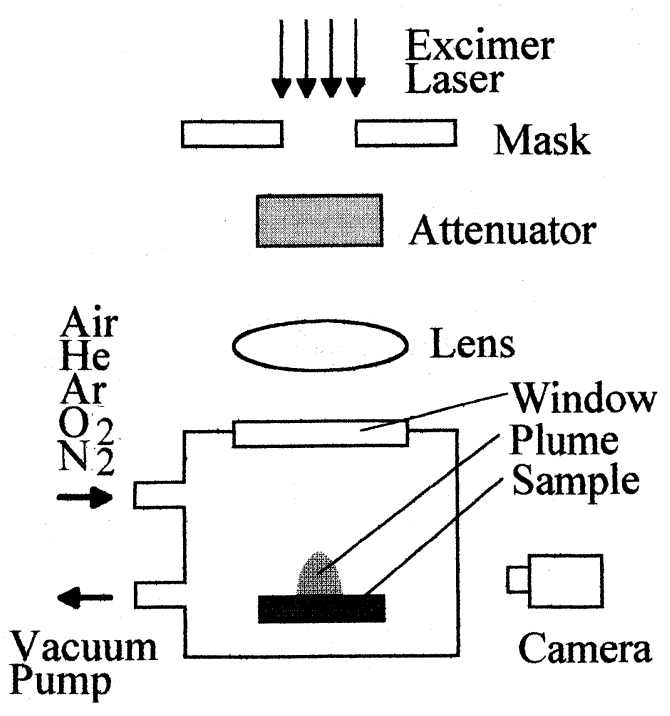

Fig. 1 Schematic illustration of the experimental apparatus for excimer laser ablation.

セラミック基板の切断工程に取り入れ実用化に 成功した。

\section{2. ポリイミド加工時のデブリー付着特性}

\section{1 実験方法}

Fig. 1に示す装置を使って, 雲囲気ガス, 真 空度, 1パルス当りのフルエンスをパラメーター

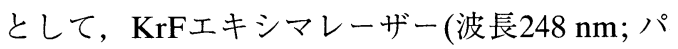
ルス幅34 ns FWHM, Lambda Physik LPX210 icc)をマスク投影することによりポリイミド(カ プトン)のアブレーション加工を行った。雲囲 気ガスは, $\mathrm{He}, \mathrm{N}_{2}$, 空気, $\mathrm{O}_{2}, \mathrm{Ar}$ の5種類, フルエンスは $1 \mathrm{~J} / \mathrm{cm}^{2}, 8 \mathrm{~J} / \mathrm{cm}^{2}$ とし, 真空度は 0.1-700 Torr(13-93,325 Pa)の間で変化させ た。加工穴径は $400 \mu \mathrm{m}$ とし，照射パルス数は， フルエンスに応じて加工深さが同じになるよう に $1 \mathrm{~J} / \mathrm{cm}^{2}$ で380で， $8 \mathrm{~J} / \mathrm{cm}^{2}$ で120と変化させた。 いずれの場合も繰り返し数は 2 ppsである。レー ザー加工中に発生するプルームの状況は35ミリ カメラで撮影した。加工部周辺の試料表面を金 属顕微鏡を用いて写真撮影し, 変色領域をデブ リーの付着範囲と定義した。 
(a)

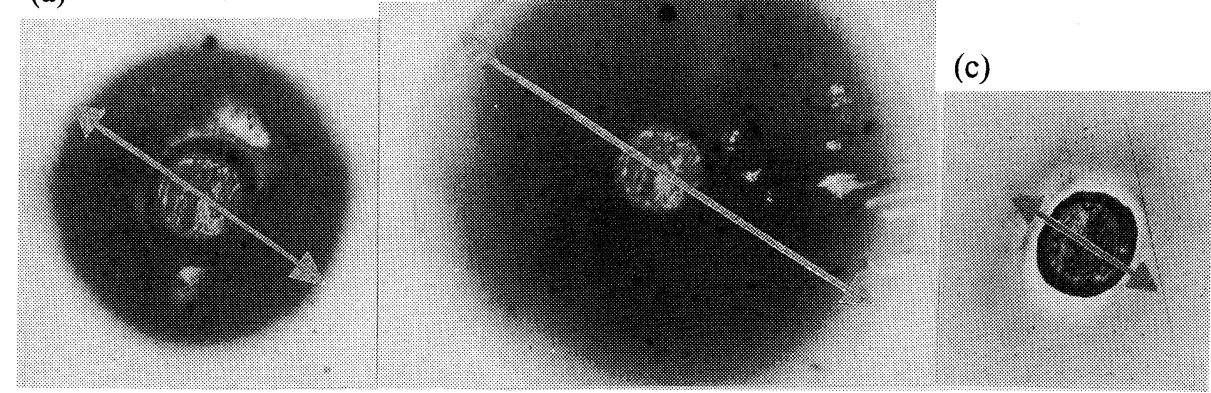

(b)

Fig. 2 Debris diameter measured with a microscope $(\times 50)$ : (a) $\mathrm{N}_{2}$ ambient, 700 Torr, $1 \mathrm{~J} / \mathrm{cm}^{2}$; (b) $\mathrm{N}_{2}$ ambient, 100 Torr, $1 \mathrm{~J} / \mathrm{cm}^{2}$; (c) $\mathrm{N}_{2}$ ambient, 0.1 Torr, $1 \mathrm{~J} / \mathrm{cm}^{2}$.

\section{2 デブリーの付着特性}

\subsection{1 付着範囲}

大気圧下ではデブリーの付着領域の輪郭は Fig. 2(a)に示すように極めて明瞭であり，エキ シマレーザーによって分解·蒸発した微粒子を 限られた領域に閉じこめる力が作用することが 示唆される。この輪郭は雲囲気ガス圧が 100 Torrでも依然として明瞭であるが，10 Torr と 更に低下すると次第に不明瞭となる。

種々の雲囲気ガスに対する真空度とデブリー の範囲の関係をFig. 3, Fig. 4に示す。フルエン スが $1 \mathrm{~J} / \mathrm{cm}^{2}$ のときは, 空気, $\mathrm{N}_{2}, \mathrm{Ar}$ 雾囲気の

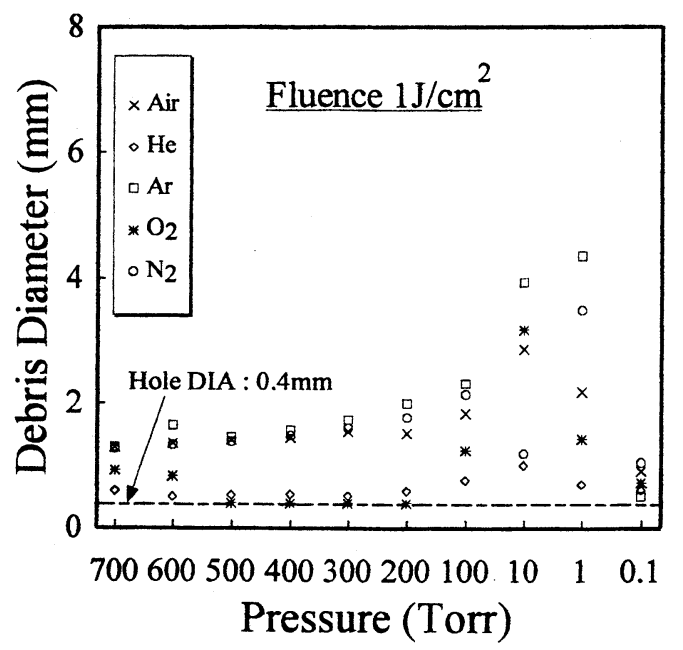

Fig. 3 Debris diameter plotted against ambient gas pressure (Laser fluence: $1 \mathrm{~J} / \mathrm{cm}^{2}$ ).

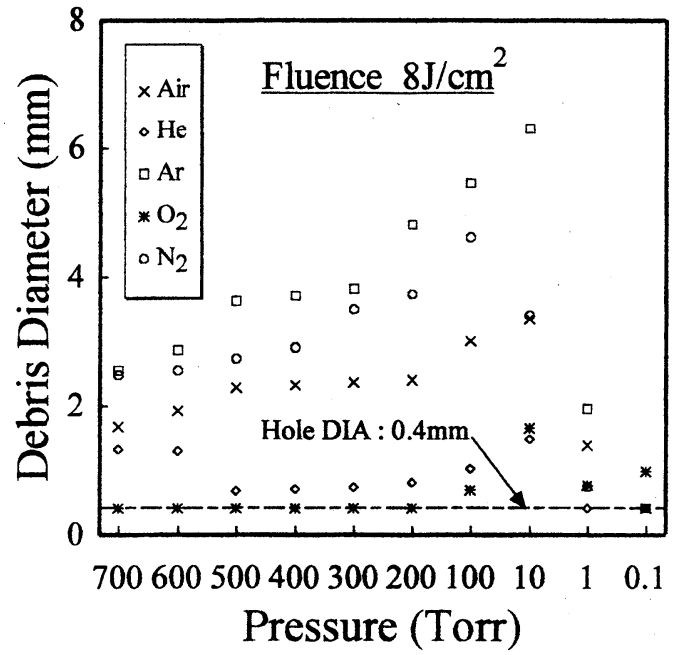

Fig. 4 Debris diameter plotted against ambient gas pressure (Laser fluence: $8 \mathrm{~J} / \mathrm{cm}^{2}$ ).

いずれの場合も $1-10$ Torrまでは，真空度を上 げるにつれ，デブリーの範囲が増加している。 1-10 Torrでは, デブリーの範囲はかなり広く なるが，デブリーの色はかなり薄くなりデブ リーの境界もわかりにくくなる。0.1 Torrまで 真空度を上げると，デブリーの付着範囲はかな り小さくなる。He䨌囲気では, 全体的にデブ リーがほとんど羿められない状態である。 $\mathrm{O}_{2}$ 雲囲気でも，200-500 Torrにおいて，デブリー がほとんど形成されない非常にきれいな加工が 得られた。これはポリイミドの分解物である 
カーボンが， $\mathrm{O}_{2}$ と反応して $\mathrm{CO}_{2}$ となるため である。 $\mathrm{O}_{2}$ 雲囲気中で，真空度が100 Torr以下 になると逆にデブリーが増えているのは，分解 生成物 $\mathrm{C}$ と $\mathrm{O}_{2}$ の反応が期待できなくなるためで ある。

一方, $8 \mathrm{~J} / \mathrm{cm}^{2}$ の時は, 空気, $\mathrm{N}_{2}, A r$ 雲囲気 においてほぼ1 $\mathrm{J} / \mathrm{cm}^{2}$ の時と同じ傾向を示すが, $1 \mathrm{~J} / \mathrm{cm}^{2}$ のときょり高いガス圧力(10 Torr以下) でデブリーの範囲が減少する方向へ向かう。ま た, 空気は, $\mathrm{N}_{2}, A r$ 雲囲気と比べて, デブリー の範囲が小さいこともわかる。これも前述した とおりで, 空気雲囲気が $\mathrm{O}_{2}$ を含むため, 一部 デブリーが $\mathrm{CO}_{2}$ となるためと考えられる。 $\mathrm{He}$ 雲囲気では，600-700，10-100 Torr を除いて は，ほぼデブリーがない状態である。 $\mathrm{O}_{2}$ 雲囲 気では，200-700 Torrにおいて，デブリーの ない非常にきれいな加工が実現できており，1 $\mathrm{J} / \mathrm{cm}^{2}$ のときと比べて, 低い真空度 $(700-600$ Torr)でもデブリーがなくなっている。

\subsection{2 付着重量}

アブレーション加工前後の試料の重量変化を 測定することにより，デブリー量を求めた。い ま，アブレーションによって形成された穴の体 積を $V$, アブレーション加工による質量減少を $M$ とすると，デブリーの付着割合 $\eta$ は(1)式よ り求められる。

$$
\eta=1-M / V \rho
$$

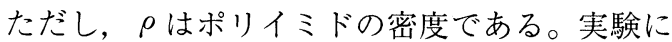
より除去された穴の表面径，底面径，及び深さ を顕微鏡にて測定し $V$ を求めた。尚，穴の内部 にもデブリーは付着し，この体積 $V$ はデブリー を含んだものになるが，付着全面積に対して， レーザー照射部分は小さいため，その量は微量 として無視してよい。また，超精密天秤(読取 り精度 $0.1 \mu \mathrm{g}$ )を用いて $M$ を測定した。(1)式に より，除去されたポリイミドのうちどれだけの 割合がデブリーとなってポリイミド表面に付着 しているのかがわかる。フルエンス $6 \mathrm{~J} / \mathrm{cm}^{2} に$ おけるデブリー付着率と真空度の関係を Fig. 5

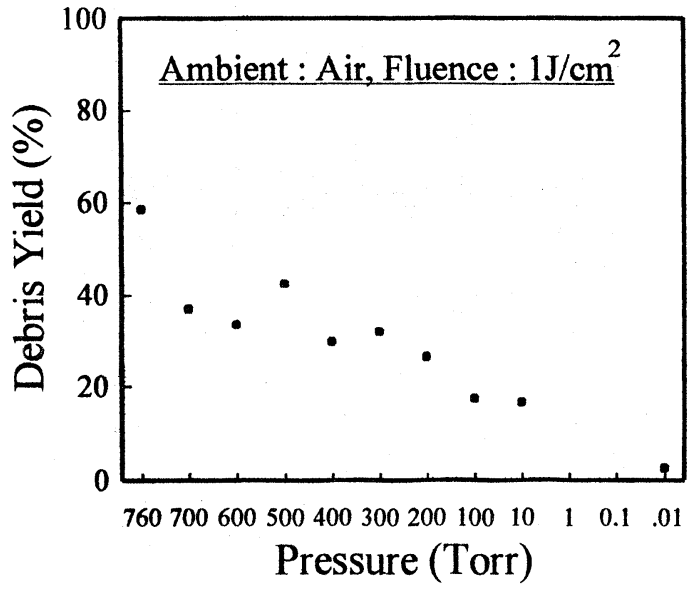

Fig. 5 Yield of debris on a polyimide surface as a function of ambient pressur.

に示す。大気圧では，除去されたポリイミドの うち約 $60 \%$ がデブリーとして周囲に付着して いることがわかる。一方，0.01 Torrに真空度 を上げると，わずか $2.5 \%$ だけがデブリーとし て周囲に付着し，ほとんどが加工表面には戻っ てこないことがわかる。以上より，50倍の顕微 鏡で発見できないようなデブリーは重量的にも 無視してよく，デブリーの顕微鏡観察によりデ ブリーの有無もほぼ評価することができること がわかった。

\section{3 プルーム観察}

Fig. 6に，真空度を変えて空気中で加工した 時のプルーム写真を示す。このとき撮影露光時 間を 0.5 秒(レーザーパルス繰返し数：2 pps) と したので，1パルスを照射したときにプラズマ プルームが発生から消滅にいたる全状況が積算 された像が撮影される。プルームは，フルエン スが高いほど大きくなり観察が容易となるの で，ここでは，フルエンスが $8 \mathrm{~J} / \mathrm{cm}^{2}$ のききの プルーム写真のみを示す。 300 Torr以上では, プルームの底面が加工物に接触しており，200 Torrになると，プルームが加工面から少し浮い た状態となる。更に真空度を上げると一方向に 噴出するようになる。プルームの形態とデブ 


\begin{tabular}{|c|c|c|c|c|c|}
\hline \multicolumn{7}{|c|}{ Pressure (Torr) } \\
\hline 700 & 300 & 200 & 100 & 10 & 0.1 \\
\hline & & & & & \\
\hline & & & & & \\
\hline \multicolumn{7}{|c|}{ Plume Width (micron) } \\
\hline 2,400 & 3,500 & 3,800 & 4,400 & 8,500 & - \\
\hline \multicolumn{7}{|c|}{ Debris Diameter (micron) } \\
\hline 1,670 & 2,360 & 2,400 & 3,000 & 3,350 & $*$ \\
\hline
\end{tabular}

$\left(^{*}\right)$ No measurable debris at $50 \mathrm{x}$ microscope

Fig. 6 Images of plume in the ablation of polyimide at various pressures (ambient: air).

\begin{tabular}{|c|c|c|c|c|c|}
\hline \multicolumn{6}{|c|}{ Gas Species } \\
\hline $\mathrm{He}$ & $\mathrm{N}_{2}$ & Air & $\mathrm{O}_{2}$ & $\mathrm{Ar}$ & $\mathrm{Kr}$ \\
\hline & & & & & \\
\hline & & & & \\
\hline \multicolumn{6}{|c|}{ Plume Width (micron) } \\
\hline 2,400 & 2,600 & 2,600 & 2,400 & 2,600 & 2,600 \\
\hline \multicolumn{6}{|c|}{ Debris Diameter (micron) } \\
\hline 1,320 & 2,480 & 1,670 & $*$ & 2,537 & 2,315 \\
\hline
\end{tabular}

(*) No measurable debris at $50 \mathrm{x}$ microscope

Fig. 7 Images of plume of polyimide in various ambient gases (700 Torr).

\begin{tabular}{|c|c|c|c|c|c|}
\hline \multicolumn{5}{|c|}{ Fluence $\left(\mathrm{J} / \mathrm{cm}^{2}\right)$} \\
\hline 8.0 & 5.0 & 4.5 & 3.0 & 2.0 & 1.5 \\
\hline & & & & & \\
\hline & & & & \\
\hline \multicolumn{5}{|c|}{ Plume Width (micron) } \\
\hline Debris Diameter (micron) \\
\hline 1,650 & 1,950 & 1,890 & 1,710 & 1,350 & 1,280 \\
\hline
\end{tabular}

Fig. 8 Images of plume of polyimide at various laser fluences (ambient: air).

リー付着状況の間には明らかに相関がありプ ルーム底面が試料面に接触しているときはデブ
リーの輪郭が明瞭であるが, 浮上すると次第に 不明瞭になり，噴出状態ではほとんど観察でき なくなる。

Fig. 7に種々の䨌囲気ガス中での700 Torr, 8 $\mathrm{J} / \mathrm{cm}^{2}$ におけるプルームの写真を示す。プルー ムのとる形状は, ガスの種類, 真空度, フルエ ンスに応じて，大きく3つのタイプに分類でき る。一つは, 台形状をしたもので, 空気, $\mathrm{O}_{2}$ 中での加工がこれに相当し, 次は, 台形状をし たプルームの上部にフレーム(炎)が現れるもの で, $\mathrm{N}_{2}, \mathrm{Ar}, \mathrm{Kr}$ の場合である。最後は, プルー ムが上方向に伸びる卵型で, $\mathrm{He}$ 中での加工や 真空度を高くした時がこれに相当する。デブ リーの量は, フレームつき台形型, 台形型, 卵 型の順となる。空気中でも, フルエンスを下げ れば, Fig.8に示すように上部にフレームが現 れる。

Fig. 8にフルエンスを変えて760 Torr の大気 中で加工した時のプルームの写真を示す。フル エンスが低下するとプルーム上部にフレームが 顕著に現れるてくることがわかる。フルエンス を増大すると，デブリーの範囲も大きくなって いくが，更にフルエンスが増大して上部にフ レームが現れなくなると，逆にデブリーの範囲 は小さくなる。本研究で行った実験の最大フル エンスは $8 \mathrm{~J} / \mathrm{cm}^{2}$ であるが，更にフルエンスを 上げると，デブリーがほとんどない状態が実現 できると思われる。 
2.4 ブラスト・ウェーブ半径とテブリー半 径との比較

エキシマレーザーをポリイミドに照射した時 に発生する衝撃波は, Srinivasanらによって研

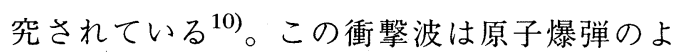
うに小さな領域に非常に大きなエネルギーが投 与されたときに発生する非定常の衝撃波で, ブ ラスト・ウェーブと呼ばれている。ブラスト. ウェーブの半径 $R$ の最大值は次式で与えら れ11)，それ以降は音波にスローダウンする。

$$
R_{0}=\left(E_{0} / P_{0}\right)^{1 / 3}
$$

$R_{0}$ : ブラスト・ウェーブのフロントを駆動する

圧力がその前方の䨌囲気圧力と等しくな る時のブラスト・ウェーブの半径

$E_{0}:$ レーザーエネルギー

$P_{0}:$ ブラスト・ウェーブ前方の雲囲気ガスの圧 力

(2)式により求められた $R_{0}$ とデブリーの付着半 径の測定值 $R_{a}$ との割合 $\left(R_{a} / R_{0}\right)$ を Fig. 9 に示し た。デブリー付着範囲は $R_{0} よ り$ 幾分小さく, $\mathrm{Ar}$ のように重いガス中では, 200 Torr以上では, $R_{a} / R_{0}$ はほぼ一定で, $R_{0}$ の約 $70 \%$ 範囲にデブ リーが広がっていることがわかる。このことは ブラスト・ウェーブ内に閉じこめられた分解生 成粒子が互いに衝突することによって，デブ リー粒子に成長することを示唆している。しか し, 100 Torr以下になると両者の比例関係は崩 れ, 付着範囲は次第に狭くなる。また, 空気, $\mathrm{N}_{2}$ などの比較的軽い雾囲気ではArより高い300 Torr で比例関係が崩れている。

デブリー粒子が, ブラスト・ウェーブ内で成 長すると考えると, ガス密度がある值より低く なると，アブレーション加工中にブラスト. ウェーブの形成が阻止されるものと考えられ る。特にHeのような低質量ガス中は, 大気圧 近辺においても $R_{a} / R_{0}$ は一定ではなくてブラス ト・ウェーブが形成されにくいものと推察され る。

Dyerらによるとレーザー照射後ただちにブ ラスト・ウェーブが形成されるのではなく，あ

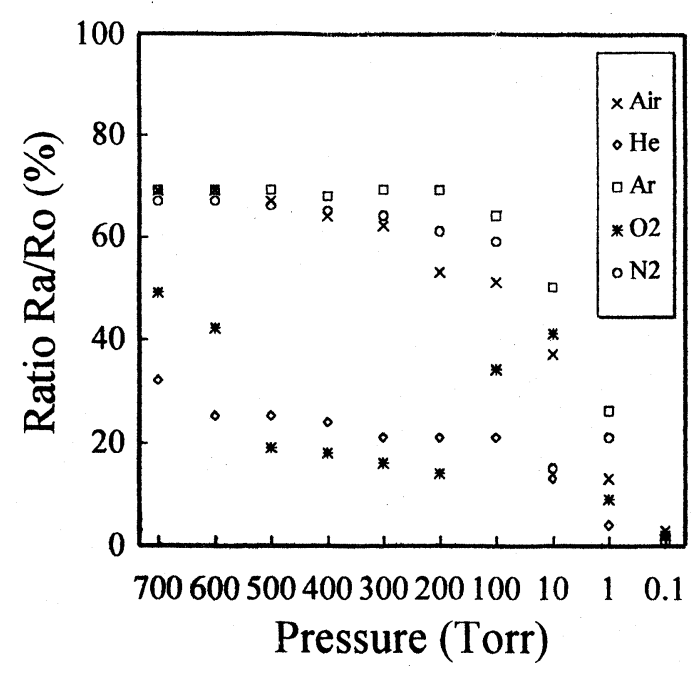

Fig. 9 The ratio of debris diameter measured with a microscope to diameter of blast wave calculated by equation (2) as a function of ambient pressure.

る時間の遅れがある。すなわち, レーザーアブ レーション加工によって除去された質量 $M_{0} に$ 比べて排除される䨌囲気ガスの質量が大きく なったとき，ブラスト・ウェーブが形成され， 次式がその形成条件である ${ }^{12)}$ 。

$$
R \gg\left(3 M_{0} / 2 \pi \rho_{0}\right)^{1 / 3}
$$

ただし， $R$ はブラスト・ウェーブの半径， $\rho_{0}$ は 雲囲気ガスの密度である。すなわち, 雲囲気ガ スの密度が小さければ，ブラスト・ウェーブは 発生しにくく, 上記の結果と一致している。な お， $\mathrm{O}_{2}$ に関しては，前述のように分解生成物 と反応するので, この理論には従わない。

\section{5 デブリーの低減法}

以上の実験結果からブラスト・ウェーブを抑 制すれば,デブリーを低減できることがわかり， Table Iにデブリーを少なくする方法をまとめ た。これは, Korenらが提案しているデブリー 付着のメカニズム ${ }^{13)}$ と一致する。彼らは, ブ ラスト・ウェーブの中心部分に生じる高温プラ ズマの放射冷却により負圧が発生し，それに伴 う冷却波が試料面に向かう強いドライビング 
Table I Debris reduction methods.

\begin{tabular}{|c|c|c|}
\hline & Methods to Reduce Debris & $\begin{array}{l}\text { Relation to } \\
\text { Blast Wave Theory } \\
\text { Eq.(2): } R=\left(E_{0} / P_{0}\right)^{1 / 3}, \\
\text { Eq.(3): } R>>\left(3 M_{0} 2 \pi\right. \\
\left.\rho_{\mathrm{o}}\right)^{1 / 3} .\end{array}$ \\
\hline 1 & $\begin{array}{l}\text { Ablation in Low Mass } \\
\text { Molecular Gas } \\
\text { Environment }\end{array}$ & $\rho_{\mathrm{o}}->$ Small (Eq.3) \\
\hline 2 & $\begin{array}{l}\text { Ablation in Vacuum } \\
\text { Environment }\end{array}$ & $P_{0}->$ Small (Eq.2) \\
\hline 3 & $\begin{array}{l}\text { Ablation at High Laser } \\
\text { Fluence }\end{array}$ & $E_{0}->$ Large $(\mathrm{Eq} .2)$ \\
\hline 4 & $\begin{array}{l}\text { Ablation in Oxygen } \\
\text { Environment } \\
\text { (in case of polymide) }\end{array}$ & None \\
\hline
\end{tabular}

フォースを形成することによってデブリー粒子 が試料表面に付着すると考察している。ブラス ト・ウェーブを抑制するためには，(3)式より加 工䨌囲気のガス密度 $\rho$ を下げるのが最も効果的 で，Table Iにおける(1)の方法で実現できる。 この方法によりプルームは台形型から卵型へ変 わる。ブラスト・ウェーブが発生してもその半 径Rが大きいほどデブリー付着量を低減できる ことが実験結果よりわかっている。これは， $R$ が大きいほど衝撃波内の分解粒子密度が低下 し，冷却波が抑制されるためと考えられる。 (2)式によるとRを大きくするには, 雲囲気圧力 を低くし，フルエンスを上げればよいことにな り，Table Iにおける(2)，(3)の方法に相当する。 この方法により, フレームつき台形型プルーム はフレームなしの台形型プルームへ変わる。ま た，ブラスト・ウェーブが発生している状況で, もうひとつのデブリーを低減する方法は, Table Iにおける(4)の方法であり, 発生した分 解物を雲囲気ガスと反応させ, ガス化させる方 法である。ポリイミドの場合, 分解物はカーボ ンと考えられており, これが $\mathrm{O}_{2}$ と反応して $\mathrm{CO}_{2}$ となり, 加工表面に付着するデブリーを大 幅に減らすことができる。

\section{3. 多層セラミック基板の配線切断工程への 応用}

\section{1 工程の問題}

ここで，実際の生産工程でデブリーがどのよ うな問題を起こすのかを紹介する。沉用コン ピューターに使われているマルチ・チップ・モ ジュールの多層セラミックス基板の薄膜層内の 配線の切断にエキシマレーザーを使用してい る。この配線の切断とその後の工程であるワイ ヤリングにより，多層セラミック基板に技術変 更を入れることが可能になる。配線の切断は, Fig. 10に示すようにポリイミド薄膜層と銅配線 層を除去するものである。そのときの問題は, デブリーが近くのボンディングパッド上に付着 し，それがその後工程であるワイヤーボンディ ングに対して悪影響を及ぼすことである。デブ リーは主にポリイミドの分解物であるスス(炭 素) と銅の酸化物である。Table Iに示したデブ リーを減少する方法の中で(2)の方法は加工部 をバキュームチャンバーに入れる必要があり,

(a)

(b)
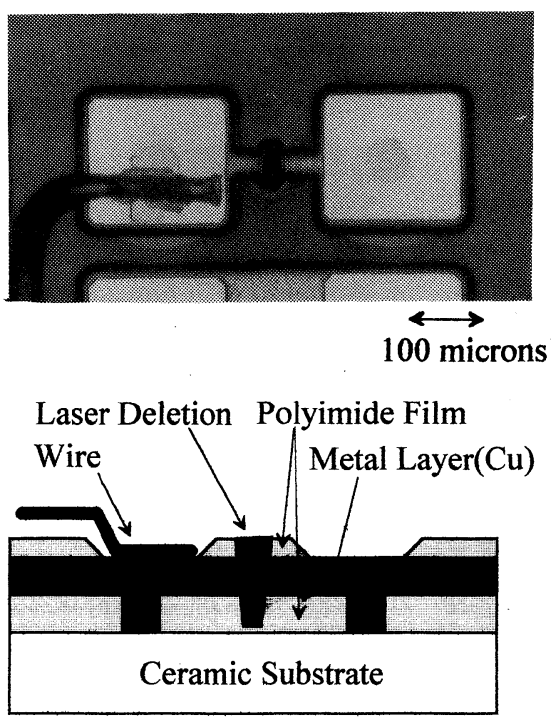

Fig. 10 Microscope picture (a) and the schematic cross section (b) showing metal line deletion above an underlying polyimide film, achieved by means of a $\mathrm{XeCl}$ excimer laser; deletion width is 25 microns. 
(A) Removal of Debris : E LASER

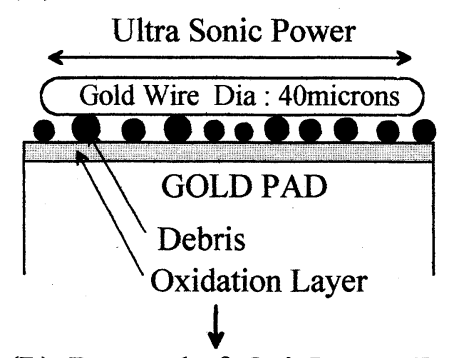

(B) Removal of Oxi. Layer : $E_{P A D}$

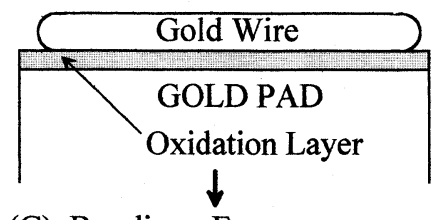

(C) Bonding : E BOND

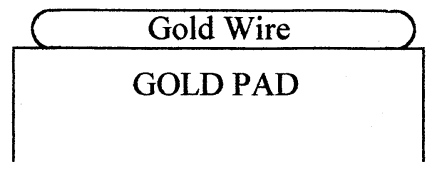

Fig. 11 Energy required for wire bonding.

装置が複雑になる欠点があり，またサイクルタ イムの増加にもつながるので，製造工程には適 さない。(4)の方法では，ポリイミドの分解物 であるススを除去することは可能だが，パッド 上への銅の酸化物の付着が増大し，ワイヤーの 強度は弱くなる。以上から，フルエンスが与え られると(1)の方法が最も有効でありこれを採 用することとした。その際, 加工上部にガスパー ジ用のノズルを取り付け，分子量の小さい $\mathrm{He}$ ガスを吹き付けながら加工するという方法を とった。

\section{2 デブリー量低減の評価}

最適のガスパージ条件を決めるために，パッ ド上にデブリーが付着している状態でボンディ ングをするときに必要とされる超音波振動エネ ルギーを求めた。Fig. 11に示すように, ワイヤ ーボンディング時に付加される超音波振動のエ ネルギーを $E_{\mathrm{TOTAL}}$ とすると，(4)式が成立する。

$$
E_{\mathrm{TOTAL}}=E_{\mathrm{LASER}}+E_{\mathrm{PAD}}+E_{\mathrm{BOND}}
$$

\section{(A)

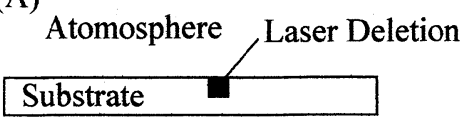

(B)

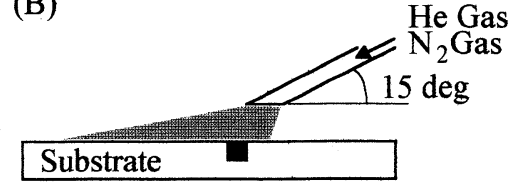

(C)
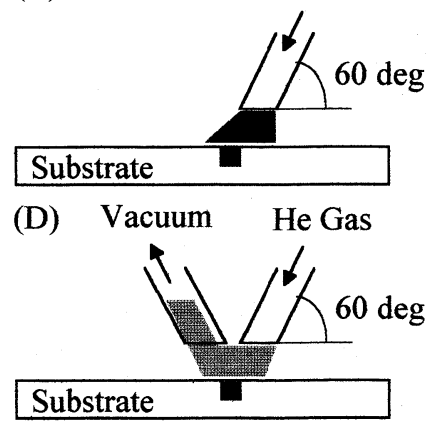

(E) Vacuum He Gas

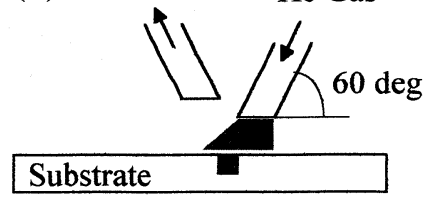

Fig. 12 Schematic illustration of the experimental apparatus for debris amount evaluation.

ただし， $E_{\mathrm{LASER}}$ はデブリーを除去するのに要 するエネルギー， $E_{\mathrm{PAD}}$ はパッド上の金属被膜 などの污れを除去するのに要するエネルギー, $E_{\mathrm{BOND}}$ はワイヤーと金パッドを接合させるの に要するエネルギーである。 $E_{\mathrm{LASER}}$ をレーザー 切断の有無によって測定される超音波振動工ネ ルギー $E_{\mathrm{TOTAL}}$ の差として求めた。

この方法を使って，Fig. 12に示すように，ガ スパージ条件を変えて, ワイヤーボンディング の強度を低下させない条件を求めた。(A)は, ガスパージをせずに，大気中で加工したもの， (B)は，15度のノズルの角度により，Heあるい は $\mathrm{N}_{2}$ ガスをパージしたもの，(C)は，60度の， ズルの角度により，Heガスをパージしたもの， (D)は, (C)の条件で, 左からバキュームノズ 
Table II Values of $E_{\text {LASER }}$ evaluated.

\begin{tabular}{lcccccc}
\hline \hline \multicolumn{1}{c}{ Equipment } & $\mathrm{A}$ & $\mathrm{B}$ & $\mathrm{B}$ & $\mathrm{C}$ & $\mathrm{D}$ & $\mathrm{E}$ \\
\hline Environ- & Air & $\mathrm{He}$ & $\mathrm{N}_{2}$ & $\mathrm{He}$ & $\mathrm{He}$ & $\mathrm{He}$ \\
ment & & Purge & Purge & Purge & Purge & Purge \\
INDEX & 100 & 81 & 120 & 9 & 67 & 12 \\
\hline \hline
\end{tabular}

ルで分解物などを吸い取るようにしたもの， (E)は, (D)の条件で, バキュームノズルの位 置をガスパージのノズルより高い位置に設定し たものである。尚, レーザーはXMR社製XeCl エキシマレーザー微細加工装置を使用し，フル エンスはすべて $15 \mathrm{~J} / \mathrm{cm}^{2}$ を使用している。

Table II に(A)の大気圧中での加工による $E_{\mathrm{LASER}}$ を 100 として，他の条件における $E_{\mathrm{LASER}}$ の值の相対值を示す。この結果から， パージガスは， $\mathrm{N}_{2} よ り \mathrm{He}$ ガスの方が $E_{\mathrm{LASER}}$ の 低減効果が大きく，またガスパージのノズルの 角度も，15度より60度のほうがよいことがわ かった。これは，15度の角度でパージすると， Heガスが広い領域に広がり，加工上部にうま くHe環境がつくれないためであると考えられ る。また, バキュームノズルに関しては, 設置 位置が難しく, $\mathrm{He}$ ノズルの近くに設定すると， He環境をつぶすことになるので, 結果的に $E_{\mathrm{LASER}}$ が増大している。しかし, 少し上に位 置をずらしてやれば,よい結果が得られている。 以上の結果より，ガスパージ法においては，如 何にうまく加工上部にHeガスの静的な雲囲気 を作るかが重要であることがわかる。

\section{4. 結言}

本研究ではエキシマレーザーによるポリイミ ドのアブレーション加工におけるデブリー付着 特性を調べるとともに，多層セラミック基板の 銅配線切断(ポリイミド層被膜)工程においてデ ブリー低減できるガスパージ法を検討した。得 られた結果は以下のように要約できる。

(1) 雾囲気ガスの密度を下げて, ブラスト. ウェーブを抑制することによりデブリー付着を 低減できる。ブラスト・ウェーブが発生する場
合には，その半径を大きくすることによりデブ リー量が低減できる。また, ポリイミドの場合 には $\mathrm{O}_{2}$ 䨌囲気中での加工がデブリー低減に有 効である。

(2) 実際の生産工程では, 真空チャンバーの中 の加工よりも大気中でのガスパージが現実的で ある。デブリー低減に有効な $\mathrm{He}$ ガスパージノ ズルを開発し，多層セラミック基板の銅配線切 断工程に適用した。

\section{謝辞}

実験にご協力頂いた，日本アイ・ビー・エム福 田勝彦氏，戸室満成氏および田村元一氏に感謝 の意を表します。

\section{参 考 文 献}

1) R. Srinivasan and B. Braren: Chem. Rev. 89 (1989) 1303.

2) J. R. Lankard Sr. and G. Wolbod: Appl. Phys. A54 (1992) 355.

3) P. J. Brofman, S. K. Ray and K. F. Beckham: IBM J. Res. Develop. 36 (1992) 929.

4) R. Srinivasan, B. Braren and R. W. Dreyfus: J. Appl. Phys. 61 (1987) 372.

5) R. J. von Gutfeld and R. Srinivasan: Appl. Phys. Lett. 51 (1987) 15.

6) G. Koren and J. J. Dnelton: Appl. Phys. B45 (1988) 45.

7) D. E. Seeger and M. G. Rosenfield: L. Vac. Sci. Technol. B6 (1988) 399.

8) S. Kuper and J. Brannon: Appl. Phys. Lett. 60 (1992) 1633.

9) D. L. Sigleton, G. Parakevopoulos, R. S. Irwin: J. Appl. Phys. 66 (1989) 3324.

10) R. Srinivasan, K. G. Casey and B. Braren: Chemtronics 4 (1989) 153.

11) Ya. B. Zel'dovich and Yu. P. Raizer: Physics of Shock Waves and High Temperature Hydrodynamic Phenomena (Academic, New York, 1966).

12) P. E. Dyer and J. Sidhu: J. Appy. Phys. 64 (1988) 4657.

13) G. Koren and U. P. Oppenheim: Appl. Phys. B42 (1987) 41. 